\title{
Continental Shelf Archaeology and International Law
}

\author{
Sarah Dromgoole
}

\section{Abstract}

This chapter outlines the international legal framework concerning the protection of submerged prehistoric resources from human activities that may cause inadvertent harm. It focuses on what is the core question from a legal perspective: to what extent does a coastal State have the jurisdictional power under international law to regulate such activities in its offshore waters with a view to protecting material of archaeological significance? As will become clear, this question is a complex one, requiring reference to three sources of international law: (i) general principles of international law, (ii) the 1982 UN Convention on the Law of the Sea and (iii) the 2001 UNESCO Convention on the Protection of the Underwater Cultural Heritage. Questions relating to the way that the relevant treaties define underwater cultural heritage, and the potential implications this may have for submerged prehistoric archaeology, though interesting, fall outside the scope of this chapter.

S. Dromgoole $(\bowtie)$

School of Law, University of Nottingham, University Park, Nottingham, UK

\section{Keywords}

12-mile territorial limit · Jurisdictional gap ·

UN Convention on the Law of the Sea .

Underwater cultural heritage · UNESCO

Convention on the Protection of the

Underwater Cultural Heritage

\subsection{Introduction}

Over the years a great deal has been written about international law in the context of marine archaeology, but for the most part, it has been addressed to the question of how to protect shipwrecks from treasure hunters, that is, from those who deliberately interfere with wrecks in order to recover items of commercial value (see, e.g. Churchill and Lowe 1988; Dromgoole 2013). From a legal perspective as well as an archaeological one, prehistoric submerged landscapes give rise to quite different questions from shipwrecks. The main threat to such landscapes is not from treasure hunters but rather from industrial and other human activities that may inadvertently damage or destroy the archaeological potential of such landscapes. Consequently, the legal means of countering the threat require specific consideration and analysis.

Prehistoric landscapes and associated archaeological remains are located on (or under the surface of) the geological continental shelf. This 
area is being subjected to increasingly intense levels of human activity that impact upon the seabed, particularly trawling by fishermen, dredging for marine aggregates, wind farm development, pipeline and cable-laying and hydrocarbon exploration and exploitation. Such activities are by no means confined to inshore waters, in other words the territorial sea and internal waters over which the coastal State has sovereignty. The North Sea Basin, an area with significant prehistoric archaeological potential, offers ample examples of offshore commercial activity taking place all across the Basin that interfere with the seabed (Peeters et al. 2009, p. 5). Gaffney et al. describe in quite striking terms the impact that trawling activity, over time, has had on prehistoric deposits on the Dogger Bank, which lies in the southern North Sea, 60 or so miles from the UK coast (Fig. 25.1). The physical infrastructure supporting the North Sea offshore oil and gas industry-rigs, pipelines and associated installations - is already immense (Fig. 25.2), and a new generation of energy-related infrastructure of substantial scale is likely to be put in place over the next two decades. The United Kingdom, for example, has ambitious plans for a rapid extension of wind farm developments beyond the 12-mile limit, as well as for the development of $\mathrm{CO}_{2}$ storage facilities deep within the seabed on the continental shelf (see the Crown Estate website at http://www.thecrownestate.co.uk).

This chapter outlines the international legal framework relating to the protection of submerged prehistoric resources from human activities that may cause inadvertent harm. It focuses on the core question from a legal perspective which is to what extent does a coastal State have the power to regulate such activities in its offshore waters, in other words those beyond the 12-mile limit, with a view to protecting material of archaeological significance, or potential archaeological significance? This question is technically complex, requiring reference to three sources of international law: general principles of international law, the 1982 UN Convention on the Law of the Sea and the 2001 UNESCO Convention on the Protection of the Underwater Cultural Heritage.

\subsection{Relevant Principles of International Jurisdiction}

To regulate activities in any geographical space, be it on land or at sea, a State must have the requisite jurisdictional power under international law. There are various general principles of international jurisdiction that provide bases for a State to take lawful regulatory action, and there are also some specific principles relating to jurisdiction in the maritime sphere. In the context of this paper, both have relevance. The two general principles of international jurisdiction that are relevant are the so-called 'territorial' and 'nationality' principles (see Churchill and Lowe 1988 and Brownlie 2008).

Under the 'territorial' principle, a State has jurisdiction to regulate activities that take place within its territory; this jurisdiction extends to the regulation of the activities of foreign parties within the territory (subject to certain exceptions). By virtue of this principle, the State can regulate all activities taking place within its territorial boundaries, and these boundaries are set by the outer limits of the territorial sea. The territorial sea-extending up to 12 nautical miles $(\mathrm{nmi})^{1}$ from coastal baselines, generally lowwater mark-is the maritime territory of the State and the State has sovereignty and jurisdiction over all activities taking place within its territorial sea, subject to various rules of international law. The main such rule is that foreign ships have a right of 'innocent passage' through the territorial sea. Ships engaged in activities that may affect underwater cultural heritage $(\mathrm{UCH})$ are unlikely to be engaged in innocent passage because innocent passage requires 'continuous and expeditious' passage. Therefore, generally speaking, the coastal State has the right to regulate activities affecting $\mathrm{UCH}$ taking place within the 12-mile limit, including activities conducted by foreigners.

\footnotetext{
${ }^{1} \mathrm{~A}$ nautical mile is defined as $1852 \mathrm{~m}$ or 1.15 miles (Briney 2018, https://oceanservice.noaa.gov/facts/nauticalmile_knot.html); therefore, $12 \mathrm{nmi}$ is equivalent to 13.8 miles or $22.2 \mathrm{~km}$. All references to miles in this chapter are to nautical miles unless stated otherwise.
} 


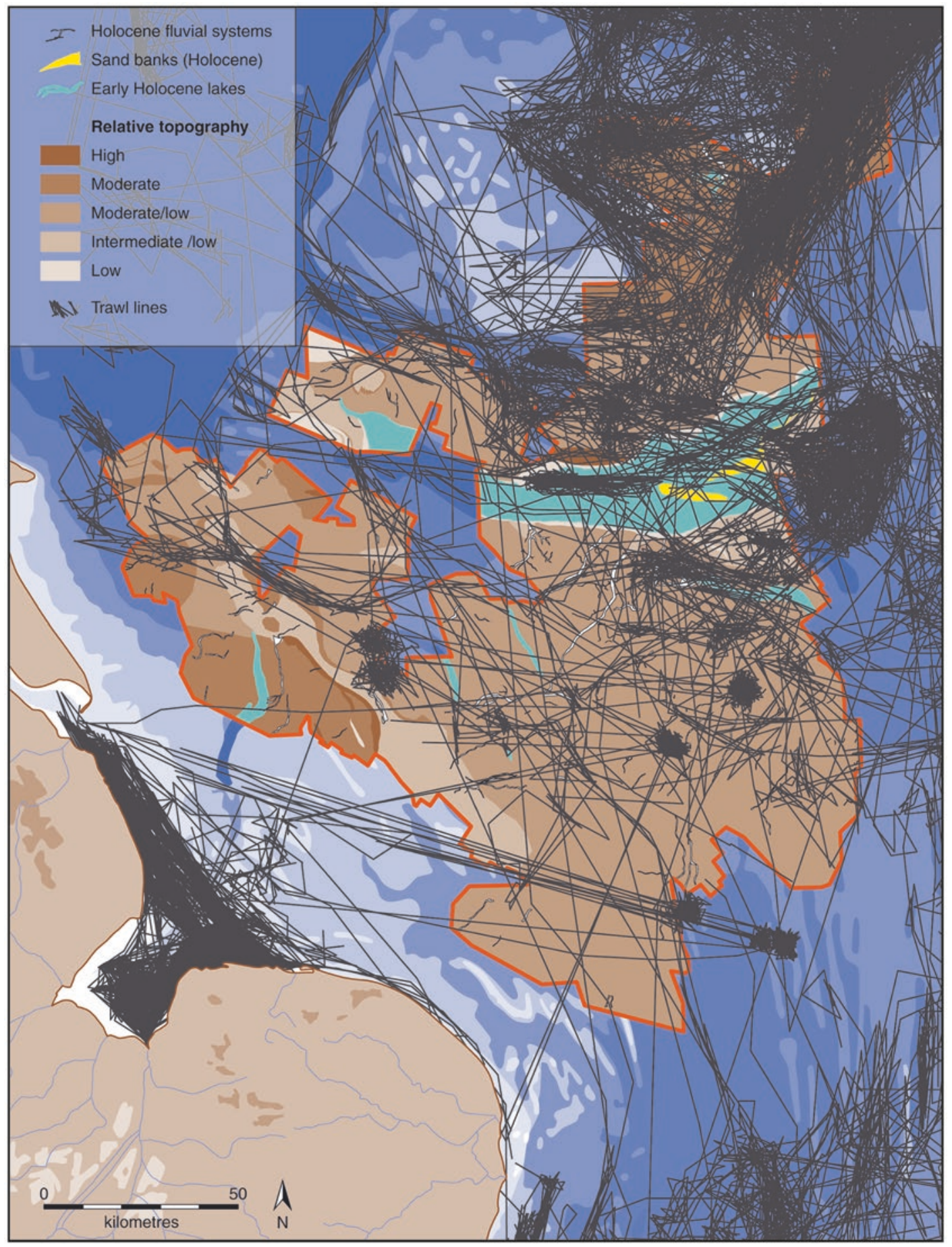

Fig. 25.1 The remarkable intensity of modern trawling activity in the southern North Sea as recorded in 2007 for UK fishing vessels $>15$ m. After Gaffney et al. (2009, p. 154, Fig. 5.17). Image created by the North Sea Palaeolandscapes Project and Henry Buglass. Courtesy of Vince Gaffney and the Council for British Archaeology 


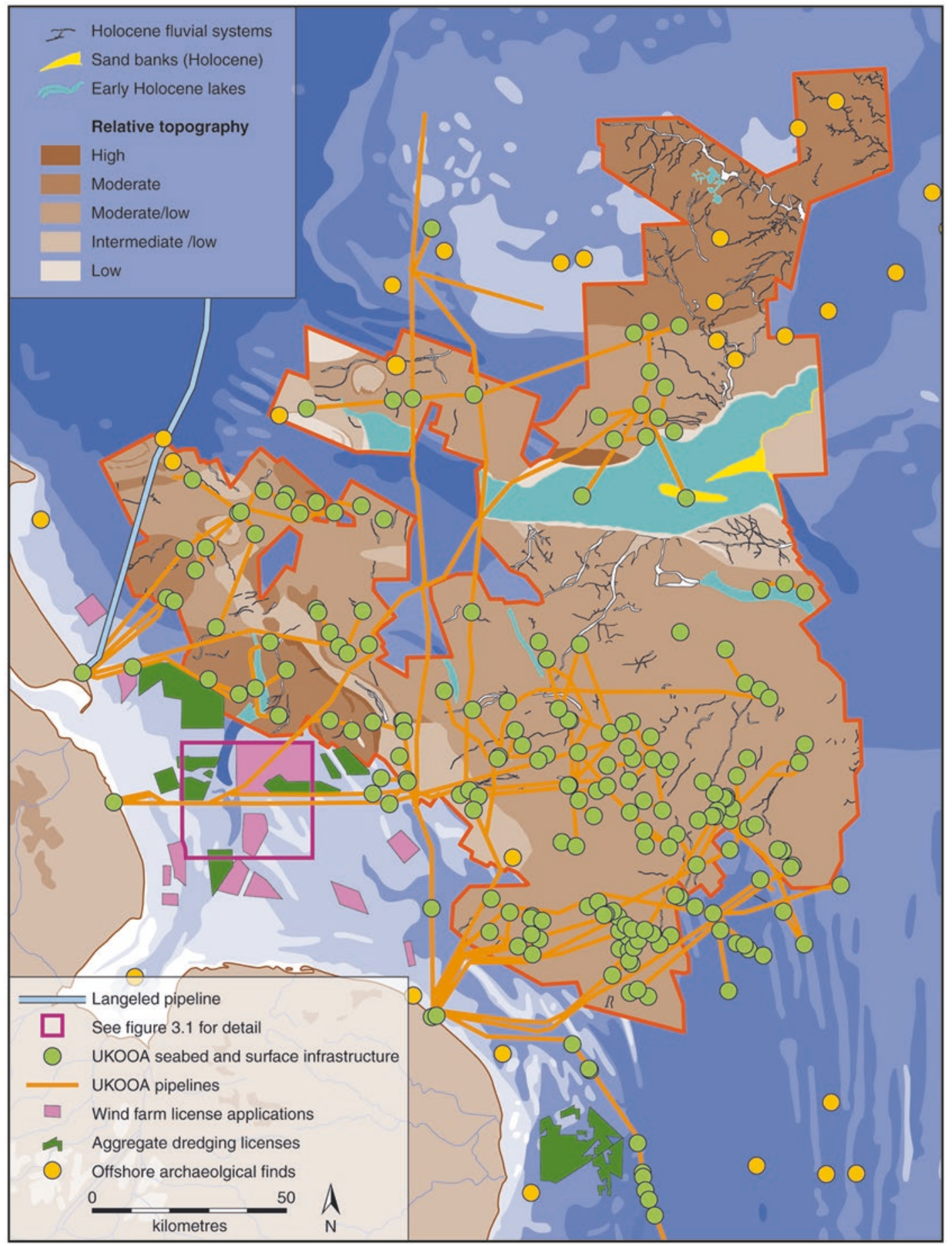

Fig. 25.2 The intense use of space within one sector of the North Sea, showing pipelines, seabed infrastructure, areas licensed for aggregate extraction and wind farms and topographic features. After Gaffney et al. (2009, p. 156, Fig. 5.19). Image created by the North Sea Palaeolandscapes Project and Henry Buglass. Courtesy of Vince Gaffney and the Council for British Archaeology 
Under the 'nationality' principle of international jurisdiction, a State has the right to regulate the activities of its own flag vessels and nationals, wherever in the world they happen to be. This means that a State can extend its jurisdictional arm out beyond its territorial boundaries but only for the purpose of controlling the activities of its own flag vessels and nationals (including corporate entities). In a maritime context, this is a useful principle when it comes to finding ways of regulating activities in international waters beyond the 12-mile territorial limit.

Aside from these general principles of public international law, there are also principles relating specifically to maritime jurisdiction. These are set out in the United Nations Convention on the Law of the Sea, the so-called Constitution for the Oceans.

\subsection{The Convention on the Law of the Sea 1982}

\subsubsection{Background}

The Convention on the Law of the Sea 1982 (LOSC for short) is a comprehensive treaty establishing the international legal framework governing human activities in the oceans. It is the longest international treaty that has ever been created, and apart from the Charter establishing the United Nations, it is also the most successful. Unlike many other treaties, the Convention on the Law of the Sea is now close to universal ratification. With the exception of a small handful of States (notable non-parties are the United States, Turkey, Peru, Israel and Iran), it has strong international support.

The Convention divides the oceans up into a number of maritime zones and establishes a legal regime for each of these zones, which sets out the rights of States (Fig. 25.3). Under the Convention, coastal States (in the sense of States with a coastline) are afforded some limited rights and jurisdiction in their offshore waters, in other words waters beyond the 12-mile territorial limit. However, for the most part, the rights and jurisdiction in these offshore areas relate only to natural resources and to the exploration and exploitation of those resources. Despite the close link that exists in practice between the natural and historic environment, sunken vessels, their contents and other man-made objects found at sea are not regarded as natural resources for the purposes of the Convention on the Law of the Sea (Dromgoole 2013, pp. 29-30). In the context of submerged landscape archaeology, archaeologists are interested in much more than merely the
Fig. 25.3 Maritime zones, showing the jurisdictional 'gap' between the areas of seabed covered by Article 149 and Article 303 of the United Nations Convention on the Law of the Sea. Distances are in nautical miles. Not to scale. See text for further discussion and definitions

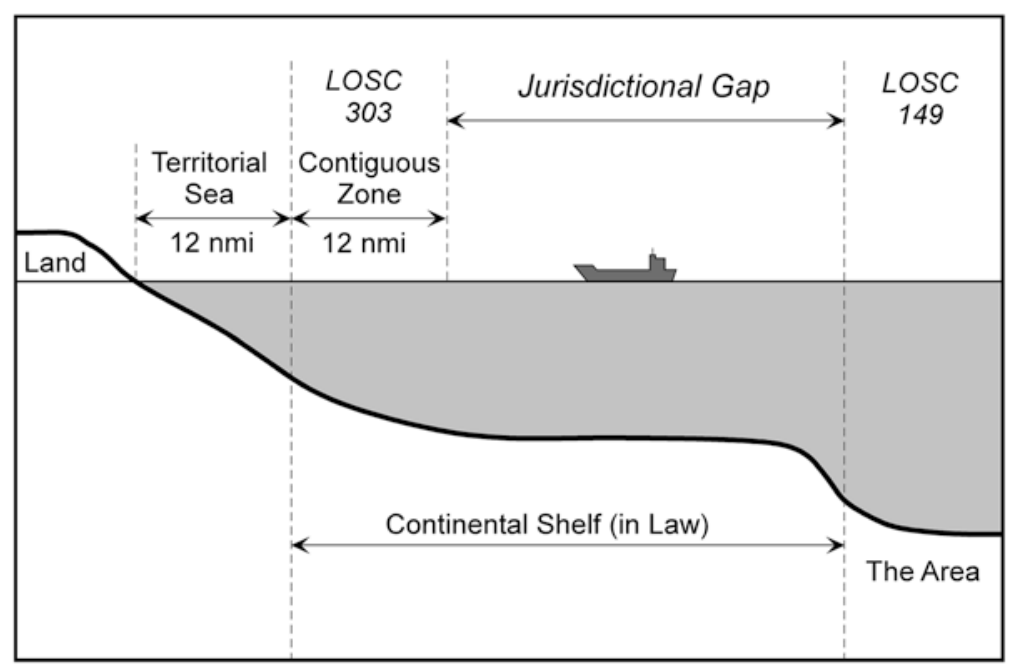


man-made objects that may be found within the landscape. Nonetheless, the whole provision for $\mathrm{UCH}$ in international law is predicated on the basis that there is a clear dichotomy between the natural and historic environments.

\subsubsection{Specific Provision for UCH: Articles 149 and 303}

When the Convention on the Law of the Sea was negotiated in the 1970s, appreciation of the nature and value of cultural resources located on the seabed was extremely limited and the main concern of the international community (or, to be more precise, a small section of that community) was to find means for protecting ancient shipwrecks and other antiquities from treasure hunters and souvenir seekers, primarily in the Mediterranean region. At the time, a few Mediterranean States argued that coastal States should be afforded the right to regulate activities affecting UCH over the whole of their continental shelf. On the other hand, a number of other States-maritime powers such as the United States, the Netherlands and the United Kingdom-argued that the rights of a coastal State over the continental shelf should be confined to natural resources only. What these and other maritime States were concerned about, and continue to be concerned about, is that if the rights of States to regulate activities in their offshore waters are extended beyond traditionally narrow confines, this will interfere with the freedom of the maritime States to navigate the seas of the world without impediment. In the context of oceans policy, freedom of navigation is nearly always the overriding imperative of maritime States.

Eventually, a compromise was reached between the two sides, although it was heavily tipped in favour of the maritime powers. Some specific provision was included in the Convention for the purposes of $\mathrm{UCH}$ protection, but it was very limited. The Convention contains two articles addressing $\mathrm{UCH}$, or, to be more precise, 'objects of an archaeological and historical nature', Articles 149 and 303. Article 149 relates to the maritime zone referred to as 'the Area', which is the deep seabed beyond the limits of 'national jurisdiction' (in practice meaning beyond the limits of the continental shelf as legally defined: see further below). The other provision, Article 303, gives coastal States the right to exercise control over the removal of $\mathrm{UCH}$ in a relatively narrow strip of sea, immediately adjacent to the territorial sea, referred to as the contiguous zone (Fig. 25.3; LOSC, Art. 303(2)). Significantly, Article 303 also establishes a general duty under international law on all States to protect UCH in all zones and to cooperate for that purpose (LOSC, Art. 303(1)).

In light of Articles 149 and 303, the position under the Convention on the Law of the Sea can be summarised as follows. By virtue of its sovereignty over the territorial sea, the coastal State has the right to regulate activities affecting $\mathrm{UCH}$ out to the 12-mile territorial sea limit; by virtue of Article 303, it also has the right to regulate the removal of $\mathrm{UCH}$ in the contiguous zone. This zone, extending from 12 to 24 miles from baselines, is one which coastal States are free to declare if they wish; it does not exist unless they declare it. The Convention also makes special provision for $\mathrm{UCH}$ in the deep seabed area in Article 149. However, between 24 miles from baselines and the outer limit of the continental shelf as legally defined, there is a 'gap' in the provision made by the Convention-it makes no specific provision for $\mathrm{UCH}$ located in this gap (Fig. 25.3).

\subsubsection{The Continental Shelf as a Legal Concept}

It is important to appreciate that there is a distinction between the extent of the continental shelf as a legal zone and the extent of the geological continental margin. Generally speaking, when lawyers refer to the continental shelf, they are referring to the legal zone of that name; this does not necessarily equate to the geological continental margin or indeed to the section of that margin referred to as the 'shelf'. 
The geological continental margin extends under the sea in widely varying ways. For some States, the continental margin falls away rapidly to the deep seabed; other States have a relatively broad continental margin; and some, a very extensive one (extending 300 miles or more from coastal baselines).

Under the Convention on the Law of the Sea, as a matter of principle, the maritime zone known as the continental shelf for all coastal States extends to at least 200 miles from coastal baselines (LOSC, Art. 76(1)), no matter how broad their physical continental margin (subject to delimitation between States with opposing coasts that are less than 200 miles apart). Therefore, even where a State has a very narrow physical continental margin or, indeed, no margin at all to speak of, it still has the rights accorded by the Convention under the legal regime for the continental shelf out to 200 miles.

Those States whose physical continental margin is broader than 200 miles (known as 'broadmargin' States) will have the rights afforded under the legal regime for the continental shelf to the physical extent of their continental margin. The 'continental margin' comprises a 'shelf', a 'slope' down to the deep seabed and a 'rise' (the area of sediment that accumulates at the bottom of the slope). In the case of broadmargin States, all three geological features are included within the maritime zone referred to as the continental shelf.

The inner limit of the continental shelf as a maritime zone is set at the outer limit of the territorial sea, in other words at 12 miles from baselines. So, the legal continental shelf starts at the 12-mile limit and extends to 200 miles or to the extent of the physical continental margin in the case of broad-margin States. This particular maritime zone is said to exist ipso facto, in other words as a matter of fact rather than as a matter of law, and therefore there is no need for the coastal State to formally claim it. The same is the case for the territorial sea.

The rights afforded to the coastal State under the continental shelf regime relate to the seabed and subsoil of the zone and to the natural resources of the seabed and subsoil; they do not relate to the water column above. The natural resources of the zone are primarily oil and gas, in other words non-living mineral resources, but they also include living resources in so far as they constitute sedentary species (as defined in LOSC, Art. 77(4)), such as oysters, clams and seaweed.

As far as the water column is concerned, the area from the 12-mile territorial sea limit to 200 miles from coastal baselines may be claimed by the coastal State as an exclusive economic zone (EEZ). The Convention on the Law of the Sea permits coastal States to claim an EEZ if they wish and, where they do so, affords the coastal State rights and jurisdiction over the natural resources of that zone. These resources include the fish in the water column and renewable energy resources generated from wind, waves and currents, but not items of cultural heritage lying on or beneath the seabed nor, indeed, items of cultural heritage found floating in the water column, such as a message in a bottle. To emphasise an important point made earlier, man-made objects are not regarded as natural resources for the purposes of the Convention on the Law of the Sea and the whole provision for $\mathrm{UCH}$ in international law is predicated on the basis that there is a clear dichotomy between the natural and historic environments (Dromgoole 2013, pp. 29-30).

One of the reasons that the legal maritime zones can be confusing is that a number of the zones overlap. For example, where coastal States claim an EEZ, their continental shelf and EEZ, as maritime zones, will overlap out to 200 miles. Also, if the coastal State claims a contiguous zone, that zone will fall within the EEZ if they claim an EEZ and will also be within the area of their legal continental shelf as well. The Convention on the Law of the Sea has different sections ('parts') setting out the regime for each of the zones, and it may be that two or even three parts of the Convention will apply to any particular spot in the ocean. In practice, generally this is not problematic as the parts have been carefully constructed to dovetail with one another. In the 
remaining sections of this chapter, references to the continental shelf are references to this zone as legally defined unless otherwise indicated.

\subsubsection{The Jurisdictional 'Gap'}

The 'gap' left by Articles 149 and 303 of the Convention on the Law of the Sea, identified above, relates to the continental shelf between 24 miles and the outer limit of the continental shelf, be that 200 miles from coastal baselines or further out to sea in the case of broad-margin States. In this area, which in the case of broadmargin States has the potential to be extensive, the coastal State is afforded no direct right by the Convention on the Law of the Sea to regulate activities affecting $\mathrm{UCH}$. The rights it is afforded in this area relate to natural resources only. All the rights and jurisdiction afforded to the coastal State in the gap are closely tied to the natural resources of the area and to matters relating to the exploration and exploitation of those resources.

Even before the ink was dry on the text of the Convention on the Law of the Sea, it was clear that Articles 149 and 303 of the Convention were inadequate to protect $\mathrm{UCH}$ in the oceans and that something needed to be done to 'plug the gap' on the continental shelf, particularly to enable coastal States to regulate treasure hunting and other activities targeting $\mathrm{UCH}-$ shipwrecks specifically-located on the increasingly accessible 'shelf' section of their geological continental margin. Even more particularly, what was necessary was a means to enable them to regulate the activities of foreign flag vessels and nationals. As pointed out at the beginning of this chapter, States have the right to regulate the activities of their own flag vessels and nationals, whichever legal zone they are in. The difficulty has been in finding a lawful means of regulating the activities of foreign vessels and nationals beyond the outer limit of the territorial sea. It should be noted that while activities targeting UCH in the 12-24-mile contiguous zone can be regulated by the coastal State by virtue of the Convention on the Law of the Sea, Art. 303(2), this provision permits the coastal State only to regulate the removal of $\mathrm{UCH}$ and therefore does not address circumstances where activities may need to be regulated to avoid inadvertent harm to UCH.

In the early 1980s, the Council of Europe attempted to create a treaty to plug the gap, which is known as the Draft European Convention of 1985. However, this initiative was unsuccessful, and the Draft Convention was never formally adopted. In the late 1980s, and in the 1990s, the problem of unregulated treasure hunting became more acute with developments in deep-water technology, and eventually UNESCO focused its attention on the matter and created the UNESCO Convention of 2001. This Convention came into force in 2009 and, at the time of writing, has been ratified by 61 parties (see http://www.unesco.org/ eri/la/convention.asp $? \mathrm{KO}=13520$ \&language $=\mathrm{E}$ \&order=alpha). In the European context, a good number of States littoral to the Mediterranean Sea and the Black Sea have become parties to the Convention (including Italy, Croatia, Bulgaria and the Ukraine, all represented in Part III of this volume). However, the picture is more mixed when it comes to the Atlantic margins and the North Sea, the focus of Part II of this volume. Here, only Portugal, Spain, France and Belgium are currently States Parties. In the Baltic Basin (the focus of Part I of the volume), the only State to have ratified the Convention to date is Lithuania.

\subsection{The UNESCO Convention 2001}

\subsubsection{Introduction}

Fundamentally, the original purpose of the UNESCO initiative was to create jurisdictional mechanisms to permit States that are parties to the Convention-operating individually and collaboratively - to regulate activities targeting UCH located beyond 24 miles, in other words, to plug the gap identified above, in order to regulate, in particular, commercial treasure hunting on the continental shelf. In fact, the Convention does much more than this, and among other things, it has the potential to impact on human activities 
that may only inadvertently cause harm to $\mathrm{UCH}$, including fishing, dredging, pipeline and cablelaying and wind farm development.

During the UNESCO negotiations, there was some debate about the extent to which such activities should fall within the remit of the Convention. While there is clearly the potential for them to cause harm to UCH (a term specifically used by the Convention and defined in Art. 1(1)), the importance to national economies of activities such as these means that any potential interference with them is a matter that is politically highly sensitive. Moreover, the negotiators recognised that attempts to regulate the multitude of activities that take place in the marine zone would be a task well beyond the remit of a UNESCOsponsored treaty. A distinction was therefore drawn between activities 'directed at' $\mathrm{UCH}$, in other words activities that have $\mathrm{UCH}$ as their primary object (UNESCO Convention, Art. 1(6)), and activities 'incidentally affecting' $\mathrm{UCH}$, in other words activities that do not have $\mathrm{UCH}$ as their primary object, or at least one of their objects, but may nonetheless disturb or cause damage to UCH (UNESCO Convention, Art. 1(7)). While a decision was made to focus on regulating the former, the Convention does not ignore the impact of activities that may inadvertently disturb, or otherwise damage, UCH. It does, however, tread carefully in relation to this issue.

As far as treasure hunting and other activities 'directed at' UCH are concerned (which include archaeological interventions), the Convention attempts to effect a compromise between those States that called for direct jurisdiction over $\mathrm{UCH}$ on their continental shelves and those Statesnamely, the maritime powers-who did not want coastal States to be afforded any further rights than those established under the Convention on the Law of the Sea. The relevant articles of the UNESCO Convention are Articles 9 and 10, which apply to the continental shelf and the EEZ (on the significance of their application to the EEZ, see Dromgoole 2013, pp. 288, fn. 45).

In light of the political difficulty of reaching agreement over this issue, these articles set out a complex web of reporting, notification and pro- tection procedures. Not only are the articles complex, but they are deeply controversial politically. The reason for this is that they have been deliberately designed so that they can be interpreted in two different ways: one that gives coastal States no greater rights than they would have under the Convention on the Law of the Sea and another that would give them greater rights (Dromgoole 2013, pp. 299-300). It was hoped that the socalled constructive ambiguities in the text would form the basis for a compromise that would be acceptable to all States; instead, the fact that the provisions can be interpreted as giving coastal States greater rights on the continental shelf than they have under the Convention on the Law of the Sea is one of the features of the Convention that has led to a reluctance on the part of the maritime powers to ratify the Convention.

\subsubsection{Principles and Objectives of the UNESCO Convention}

Before considering what the UNESCO Convention has to say about activities incidentally affecting $\mathrm{UCH}$, the core principles and objectives of the Convention (enshrined in Article 2 and elaborated upon in the Rules set out in the treaty's Annex) should be noted:

(i) The Convention is designed to ensure that activities 'directed at' UCH are conducted in accordance with internationally accepted archaeological standards. Those standards, enshrined in the Convention's Annex, have been widely praised, including by the maritime powers.

(ii) The overall objective of the Convention is to ensure that UCH is preserved for the benefit of humanity as a whole.

(iii) The Convention adopts the precautionary principle that preservation in situ should be the starting point when the competent national authorities are called upon to consider the future of any particular UCH site. This means that deliberate interference should be permitted only where justified for sound scientific reasons. 
(iv) Where authorisation has been given for the recovery of $\mathrm{UCH}$, the material recovered as far as possible must be kept together as a collection and made accessible to the general public and researchers.

(v) A cardinal principle of the Convention is that $\mathrm{UCH}$ must not be commercially exploited and the application of salvage law to the recovery of $\mathrm{UCH}$ is also severely restricted.

(vi) Responsible non-intrusive public access to $\mathrm{UCH}$ in situ is encouraged.

(vii) States Parties to the Convention must cooperate with one another in the interests of $\mathrm{UCH}$ protection.

\subsubsection{Approach Taken to Activities 'Incidentally Affecting' UCH}

How, then, does the UNESCO Convention deal with activities incidentally affecting $\mathrm{UCH}$ ? The core provision on this is Article 5; indeed, this is the only article of the Convention devoted to such activities. The article places States Parties under a specific duty with respect to such activities:

Each State Party shall use the best practicable means at its disposal to prevent or mitigate any adverse effects that might arise from activities under its jurisdiction incidentally affecting $\mathrm{UCH}$.

Article 5 does not make reference to any specific maritime zones but instead applies to activities 'under [the] jurisdiction' of States Parties. What a State Party must do under the article is use the 'best practicable means at its disposal' to prevent or mitigate adverse effects.

The obligation in Article 5 is relatively 'soft'. The provision does not give States any new jurisdictional rights, but simply requires them to make the best use of the rights and jurisdiction already available to them to prevent or mitigate adverse effects. Although the principle of preservation in situ is one of the cornerstones of the Convention, it is recognised that in some circumstances preservation in situ simply may not be practicable and that mitigation of adverse effects may be all that is possible. It should be noted that when deliberate interference with $\mathrm{UCH}$ is found to be necessary to mitigate the negative impact of activities 'incidentally affecting' $\mathrm{UCH}$, the interference will amount to an activity 'directed at' $\mathrm{UCH}$ and thus will become subject to the authorisation procedures in the Convention and will need to be conducted in accordance with the Rules in the Annex. There is no requirement that States Parties to the Convention establish new or additional regulatory frameworks; instead, Article 5 requires that they make use of, and develop, the regulatory frameworks that are already in place.

Although Article 5 is the only article of the UNESCO Convention devoted to activities incidentally affecting $\mathrm{UCH}$, consideration of this article alone is insufficient to appreciate the extent of the potential impact of the Convention on activities incidentally affecting $\mathrm{UCH}$ taking place on the continental shelf. The Convention's specific regulatory scheme for this zone, set out in Articles 9 and 10, must also be taken into account.

The fact that Articles 9 and 10 have the potential to impact on activities incidentally affecting $\mathrm{UCH}$ is obscured by the general complexity of these articles. However, a close reading of the reporting provision set out in Article 9(1) will show that it extends to the reporting of discoveries by anyone undertaking activities on the continental shelf, not just by those who intend to engage in activities directed at UCH. Exactly who will be obliged to report in practice depends on the way that the coastal State Party interprets the provision. For example, it seems likely that any States in northern Europe signing up to the UNESCO Convention will interpret it strictly in accordance with the Convention on the Law of the Sea; as a result, this means that probably they would require only the reporting of discoveries by their own flag vessels and nationals apart from circumstances where flag vessels and nationals of other States fall within their regulatory powers by virtue of the fact that they are engaged in activi- 
ties relating to the exploration and exploitation of the natural resources of the continental shelf or EEZ (see further below).

For commercial operators, a duty to report discoveries may not, of itself, be particularly worrisome. What is likely to be of greater concern is the potential consequences of making a report. Under the UNESCO Convention, any report of a discovery will trigger various procedures set out in Articles 9 and 10 relating to the notification of interested States and the protection of the $\mathrm{UCH}$ in question. However, any measures taken by States Parties under these articles-in so far as they relate to activities incidentally affecting $\mathrm{UCH}-$ should be regarded as an implementation of the general duty with respect to such activities set out in Article 5. That duty relates to activities 'under [the] jurisdiction of States Parties'. It therefore reinforces the fact that a State may only take action to regulate activities to the extent that it already has the jurisdiction to take such action.

This leads to the question: when does a State have jurisdiction to take regulatory action with respect to activities 'incidentally affecting' $\mathrm{UCH}$ under general international law, in other words outside the UNESCO Convention's framework, when those activities are being undertaken beyond the 12-mile territorial limit?

\subsection{Jurisdictional Position Under General International Law: Summary}

The jurisdictional position under general international law with respect to activities 'incidentally affecting' UCH is essentially threefold:

(i) If, by virtue of the 'nationality' principle of international jurisdiction, the coastal State has jurisdiction over a vessel, a company or an individual working on the continental shelf, or planning to work on the continental shelf, then it will have the right to regulate the activities in the interests of $\mathrm{UCH}$ protection. (ii) Where the coastal State has jurisdiction over the activities of foreign companies on the continental shelf/in the EEZ by reason of the fact that they are engaged in the exploration and exploitation of the natural resources of these zones, then the coastal State probably has a right to require the reporting of $\mathrm{UCH}$ finds, and the appropriate treatment of any such finds, under the terms of the licence that it grants to that company. Justification for the imposition of reasonable conditions designed to protect $\mathrm{UCH}$ is probably provided by the fact that the Convention on the Law of the Sea imposes a general duty on States to protect UCH in all maritime zones under Article 303(1). Greece and Norway appear to have been the first States to have imposed such conditions on contractors working on the continental shelf, but as far as it is possible to tell, the practice appears to be quite prevalent today, certainly in northern Europe (Dromgoole 2013, pp. 266-267; see Pater, Chap. 26, this volume, for an English example, and Chapters in Parts I and II, this volume, for further detail).

(iii) In the case of activities incidentally affecting UCH which do not fall under (i) or (ii) above, and therefore are not subject to direct coastal State jurisdiction, in some circumstances, the coastal State may be able to make indirect use of the jurisdiction afforded to it in respect of the natural resources of the continental shelf and EEZ in order to protect UCH. For example, if the activities amount to drilling into or other disturbance of the seabed, or if they amount to the dumping of waste onto the seabed, then the coastal State may well have a right to regulate them and, by doing so, to indirectly afford protection to UCH (Dromgoole 2013, pp. 267-272).

The three methods of regulating activities set out above are available to States under general international law, in other words under the international legal regime existing outside the 
UNESCO Convention. What the UNESCO Convention does by way of addition to this position is to impose a legal duty on States Parties to that Convention to make full use of these jurisdictional methods to prevent or mitigate adverse effects on UCH. It should be noted that the methods are available to all States in any event, but the problem is that they do not necessarily make use of them. It is worth noting too that, by applying to archaeological heritage 'located in any area within the jurisdiction of the Parties', the Council of Europe's regional treaty, the 1992 Valletta Convention, has had the effect of encouraging some States to make full use of the jurisdictional tools available to them in their offshore zones in the interests of $\mathrm{UCH}$ protection.

\subsection{A Special Case: Pipelines and Cables}

The pipeline and cable industries must be distinguished from other offshore industries because they are afforded a privileged position under the Convention on the Law of the Sea. Among other things, this means that the nationals and flag vessels of foreign States are entitled to lay submarine cables and pipelines on the continental shelf of a coastal State, generally speaking without impediment by the coastal State (LOSC, Art. 79). Nonetheless, there is a significant proviso to this general rule in the case of pipelines and that is that the delineation of their course is subject to the consent of the coastal State (LOSC, Art. 79(3)). Again, given the general duty on States under Article 303 of the Convention on the Law of the Sea to protect UCH in all maritime zones, it would appear to be justifiable for the coastal State to require that new pipelines avoid areas of particular archaeological sensitivity.

\subsection{Concluding Remarks}

Since the emergence of interest in marine archaeology in the 1950s, the debate concerning UCH and international law has focused almost exclusively on the question of how to regulate the activities of those that deliberately target $\mathrm{UCH}$ and, more specifically, shipwrecks. Until such time as the 2001 UNESCO Convention fulfils its fundamental objective of establishing a globally effective regime for the conduct of activities 'directed at' UCH, this question will continue to attract attention. However, in view of the relentlessly increasing pressures on the marine environment as a result of offshore human activity, as well as burgeoning interest in the archaeological potential of submerged landscapes, it is likely that greater attention will be paid in the future to activities 'incidentally affecting' $\mathrm{UCH}$ and to State practice relating to the regulation of such activities in the interests of $\mathrm{UCH}$ protection. This should help to bring greater clarity and certainty to the question of what States can, and cannot, do legitimately under international law to protect $\mathrm{UCH}$ from the adverse effects that such activities may have. Of course, much can be done without recourse to law by means of voluntary agreements and codes of practice. In this respect, the building of understanding through dialogue between offshore developers and archaeologists has already resulted in a number of important joint research initiatives in the North Sea in particular (see Peeters and Amkreutz, Chap. 8, this volume; Bailey et al., Chap. 10, this volume) and has been a major strand in the SPLASHCOS agenda (https:// www.splashcos.org/outreach/collaboration). Such a dialogue has a vital role to play in future offshore research.

Acknowledgements This chapter arises from a paper delivered at the SPLASHCOS international conference and networking event, 'Offshore Industry and Archaeology: A Creative Relationship', held in Esbjerg, Denmark, in 2013. I thank Thijs Maarleveld for the invitation to participate in the original conference and Geoff Bailey for the invitation to turn the paper into a chapter for this volume.

\section{References}

Briney A (2018) How are nautical miles measured? https://wwwthoughtcocom/what-are-nauticalmiles-1435097, updated 16 March 2018, Accessed 25 Jan 2019 
Brownlie I (2008) Principles of public international law. Oxford University Press, Oxford

Churchill R, Lowe V (1988) The law of the sea. Manchester University Press, Manchester

Dromgoole S (2013) Underwater cultural heritage and international law. Cambridge University Press, Cambridge
Gaffney V, Fitch S, Smith D (2009) Europe's lost world: the rediscovery of Doggerland, CBA Research Report 160. Council for British Archaeology, York

Peeters JHM, Murphy P, Flemming NC (2009) North Sea prehistory research and management framework (NSPRMF) 2009. Cultural Heritage Agency, Amersfoort

Open Access This chapter is licensed under the terms of the Creative Commons Attribution 4.0 International License (http://creativecommons.org/licenses/by/4.0/), which permits use, sharing, adaptation, distribution and reproduction in any medium or format, as long as you give appropriate credit to the original author(s) and the source, provide a link to the Creative Commons licence and indicate if changes were made.

The images or other third party material in this chapter are included in the chapter's Creative Commons licence, unless indicated otherwise in a credit line to the material. If material is not included in the chapter's Creative Commons licence and your intended use is not permitted by statutory regulation or exceeds the permitted use, you will need to obtain permission directly from the copyright holder. 